\title{
Have Developing Countries Gained From the Marriage Between Trade Agreements and Intellectual Property Rights?
}

\author{
Sumner J. La Croix and Denise Eby Konan \\ UH-Manoa Economics Working Paper No. 06-5
}

March 3, 2006

\begin{abstract}
Have developing countries gained from the incorporation of IPR standards into the WTO framework? We use historical, theoretical, and empirical methods to answer this question and reach several conclusions. First, U.S. history provides a clear case of a developing country which used strong patent rights and weak copyrights in the 19th century to enhance its growth prospects. Second, recent theoretical literature presents a strong case for welfare gains to developing countries from patent harmonization if developed countries pay lump-sums to offset higher royalty payments by developing countries. Third, the creation of intellectual property in new types of inventions is necessary, but the scope, depth, and enforcement of IPRs is likely to differ across countries according to their economic and political institutions, their per capita income, and their capability to engage in and disseminate the fruits of R\&D.

JEL Classification: K33, F13, O34

*La Croix is Professor, Department of Economics, University of Hawaii-Manoa, 2424 Maile Way, Rm 542, Honolulu, Hawaii 96822; e-mail: lacroix@hawaii.edu; Konan is Interim Chancellor, University of Hawaii-Manoa, and Professor, Department of Economics, University of Hawaii-Manoa; e-mail: konan@hawaii.edu. The authors thank Matthew Pennaz for excellent research assistance; participants in seminars at the University of Hawaii, the European Institute of Japanese Studies, Stockholm School of Economics, and the 2005 Pacific Asia Free Trade and Development Conference for their thoughtful comments; and Walter Park for supplying us with data. We are responsible for all errors of commission and omission.
\end{abstract}




\section{Introduction}

In 1995, the new WTO Agreement included an extensive set of rules governing Trade-Related Intellectual Property Rights (TRIPS). TRIPS established minimum standards for copyright, patent, trademark, trade secrets, and geographical indications; specified public and private methods to enforce these rights; and provided developing countries with additional time to meet these goals. During the ensuing ten years, governments, international institutions, and individuals have increasingly questioned whether developing countries are gaining from the marriage of trade agreements and intellectual property law.

Our analysis begins by examining the nineteenth-century development of the emerging economic power, the United States, and the role that intellectual property rights played in their development. We find that the United States provided strong patent protection to domestic and foreign innovators and no copyright protection for foreign authors during much of the nineteenth century. We note that many of the IPR policies adopted by the United States in the nineteenth century are now prohibited by TRIPS rules requiring equal treatment of foreign and domestic copyright holders. We then show how changes in the structure of U.S. industries over the course of the last 125 years have induced major changes in U.S. IPR policy. After extensive bilateral pressure on both developed and developing countries during the 1980s and 1990s, the United States joined the European Union in pushing for the incorporation of minimum IPR standardsTRIPS — in the 1995 WTO treaty.

We provide an overview of the major TRIPS provisions and then examine in more detail the major developments in international IPR law since TRIPS. The main 
developments are: (1) the United States and the European Union continue to press for establishment of IPRs in "new” fields of intellectual innovations, including genetically modified plants and animals, computer software, business methods, and chip designs; (2) the United States and the European Union strengthen their copyright and patent protection in a number of product categories along numerous dimensions and initiate efforts to negotiate so-called "free trade area” (FTA) agreements with developed and developing countries that require trading partners to strengthen their IPR laws and enforcement; (3) the United States and the European Union join the World Copyright Treaty (WCT) which prohibits de-encryption devices, breaking encryptions, and distributing copyrighted products using channels not allowed by their owners; and (4) the resistance of developing countries in Asia and elsewhere to the three developments identified above.

We examine recent theoretical literature on global IPR harmonization to determine whether IPR patent harmonization should be expected to generate increases in global welfare. Our review focuses on the two-country model developed by Gene Grossman and Edwin Lai (2003), as this model generates a pattern of patent harmonization that is broadly consistent with the pattern established in TRIPS. Grossman and Lai find that patent harmonization should lead to an increase in the strength of patent protection in both developed and developing countries and an increase in world welfare if developing countries are provided with compensation for the increased flow of rent transfers to developed countries that occurs under the harmonized patent system. 
Fourth, we consider how the internet and digitization of copyrighted works have affected copyright piracy within and across countries. Digitization has reduced the cost of copying most copyrighted material and requires changes in copyright law if these works are to be optimally protected. The internet has facilitated both national and international piracy of copyrighted digitized works. As knowledge-intensive services become a bigger component of GDP, copyright law is assuming a more prominent role in GDP growth. We consider whether the combination of the internet and digitization require changes in national copyright laws and the TRIPS Agreement.

A brief conclusion finds that the creation of intellectual property in new types of inventions is necessary, but that the scope, depth, and enforcement of IPRs is likely to differ across countries according to their economic and political institutions, their per capita income, and their capability to engage in and disseminate the fruits of R\&D.

\section{Are Strong IPRs Necessary for Development? The Case of the United States}

Are IPRs necessary for economic development? Robert Evenson and Larry Westphal (1995) and Keith Maskus (2000) have correctly argued that a simple package of intellectual property rights is likely to enhance GDP growth rates even in very lowincome countries. Elhanan Helpman (1993) Sumner La Croix and Denise Konan (2002), and T.N. Srinivasan (2000), among others, have argued that excessive protection can lead to a transfer of rents to developed countries, restrain consumer access to new goods, and make it more costly for nascent R\&D efforts to develop new products that will find a market in the home country or foreign countries. 
One way to consider the question is to look to history and examine the interaction between IPRs and economic growth for the countries which industrialized during the nineteenth century—-today’s developed countries. Zorina Khan and Kenneth Sokoloff (2001, 235) observed that the system of patent rights established in Britain had numerous features that "reflected its origins in royal privilege." Several officials needed to approve the patent application; high fees were charged to file a patent application; access to the patent's design was restricted until its expiration; patents could be obtained on technologies discovered by a third party outside Britain, and the patent had to be used inside Britain (“working requirements”) to remain in force. Britain was not alone in allowing foreign discoveries to be patented by a British third party without the consent of the original discover; other countries, including France and the Netherlands also allowed the patenting of pirated technologies. These provisions meant that domestic intellectual property laws in Europe's leading countries actually encouraged the pirating of foreign technologies during the first half of the nineteenth century.

Khan and Sokoloff (1998) found that the framers of the U.S. Constitution and the legislators in the first sessions of the U.S. Congress were familiar with British precedent and consciously innovated when they considered intellectual property. The Constitution specifically provides the U.S. Congress with the power " $[\mathrm{t}] \mathrm{o}$ promote the Progress of Science and useful Arts, by securing for limited Times to Authors and Inventors the exclusive Right to their respective Writings and Discoveries”1 In its first session, the U.S. Congress passed a revolutionary patent law that provided for low application fees, impersonal patent examination, grants only to the original discover, and disclosure of the

\footnotetext{
${ }^{1}$ Article 1, Section 8, U.S. Constitution.
} 
invention's specification upon issuance of the patent. ${ }^{2}$ Kahn and Sokoloff argued that easy access to the U.S. patent law, speedy judicial remedy of disputes over patents, and access to large, new markets led to three important results. First, there was a surge in the per capita patenting rate over the course of the nineteenth century, with an increase of 1,500 percent recorded between the 1840s and the 1870s. Second, a larger percentage of inventors were more likely to specialize in inventive activity (Lamoreaux and Sokoloff, 1996, 1999). Third, the well-defined patent rights and specialization in inventive activity spurred the development of sophisticated technology markets in the mid-nineteenth century. Patent agents and lawyers not only facilitated the filing of patent applications, but also acted to match potential buyers and sellers of patented technologies and to match potential investors with inventors of new technologies.

The response to the highly productive American system differed across countries. In 1852, the leading political and economic power-Great Britain—strengthened its patent laws to bring them more into accordance with American practices. Two small countries reacted very differently. The Netherlands eliminated it patent system in 1869 and did not restore it until 1912, while Switzerland radically weakened its patent law in 1850 and did not restore effective patent rights until 1907 (Schiff 1971). ${ }^{3}$

Numerous scholars (Griliches1994; Mowery 1983, 1995; Lamoreaux and Sokoloff 1999) have discussed the long-term decline in patenting rates by U.S. residents which began in the late nineteenth century and did not reverse course until the early the

\footnotetext{
${ }^{2}$ The Patent Law of 1836 introduced the modern system of patent examination which provided for examination of patent applications by skilled examiners. Issues previously resolved by expensive and lengthy civil litigation were, after the 1836 legislation, resolved by examiners in the U.S. Patent Office.

${ }^{3}$ This helps to explain how Albert Einstein found the time to develop the theory of special relativity and to earn a doctorate while working at the Swiss Patent Office from 1902 to 1909.
} 
1980s. While some of the change may have been due to the increased prevalence of research activities within large corporations, Lamoreaux and Sokoloff $(1999,2003)$ also speculate that a series of federal court rulings between 1890 and 1920 reducing the scope of patent claims and establishing clearer rights in the use of other forms of contract and property law to protect inventions had the effect of reducing the expected value of a patent. This led firms to choose other, more effective instruments (trade secrets, restrictive covenants, rights to employee patents) to establish rights to their inventions. The long-term trend in patent protection in the United States is surprising: strong patents rights during the nineteenth century, weaker patent rights from early twentieth century to the 1980s and stronger patent rights covering a larger spectrum of inventions since the early 1980s.

At the 1883 Paris Conference on international patent rights, there was conflict between the United States, which favored a patent system with reciprocal rights (they provide incentives to countries with weaker patent systems to upgrade) and with few exemptions, while Great Britain and France wanted a weaker system with national treatment (it provides few incentives to countries with weaker systems to upgrade) and compulsory licensing. The final agreement was a blow to U.S. interests as it adopted national rather than reciprocal treatment as the required standard for patent law.

U.S. copyright law followed a very different course. The first U.S. copyright law (enacted in May 1790) "secured the copies of map, charts, and books to the authors and proprietors of such copies” after registering their copyright, depositing the copy, notifying the public, and paying a nominal fee. Judicial decisions and legislative amendments changed the copyright law substantially during the nineteenth century, with 
U.S. courts weakening protection by recognizing the doctrines of fair use, first sale, and work for hire and expanding protection by increasing copyright terms, extending copyright protection to new products, such as photographs, lithographs, and records, and providing protection to derivative products, such as translations and performances.

A major contrast between American and European copyright laws at the beginning of the nineteenth century was that American law did not provide protection for foreign copyright, while copyright laws in Great Britain and France protected foreign copyrights. By contrast France and Britain both recognized foreign copyrights (subject to reciprocity and home publication) early in the nineteenth century and granted national rights to foreigners by mid-century. Their copyright stances are consistent with their respective positions as the suppliers of literary and nonfiction works to millions of French- and English-speaking residents in current and former colonies. It is unsurprising that France was the leader in this drive, as France was more likely than Great Britain to remain a net supplier of literary and nonfiction works to its numerous small colonies given the respective sizes of the home market and colony markets. By contrast, government officials in Great Britain surely recognized that it would become a net importer of copyrighted material as population and income in its former colonies, particularly the United States, surpassed that of Great Britain.

Between 1820 and 1890, American and European authors regularly lobbied the U.S. Congress to change this provision and were opposed by U.S. publishers. An 1841 Convention between Great Britain and the United States providing for recognition of foreign copyrights was not even considered by the U.S. Senate. In 1883 the U.S. government turned down an invitation to attend a conference in Berne organized to 
consider international harmonization of copyright law and refused to sign the 1886 Berne Convention. Khan and Sokoloff (2001) assert that the growth of the American literary sector in the late nineteenth century may have increased the demand for American books in foreign countries sufficiently to induce a change in the wealth-maximizing U.S. policy. Thus, as the U.S. switched from being a net importer to being a net exporter of copyrighted goods, Congress responded in 1891 by amending the U.S. copyright law to recognize foreign copyrights. ${ }^{4}$

The U.S. recognition of foreign copyrights was not retroactive, i.e., work already in the public domain remained there. From the perspective of wealth maximization, this is understandable as the stock of valuable prior work was predominately that of British authors. Establishing copyright in the already existing stock of books could increase neither the quality nor quantity available to the U.S. public — and it prevented the payment of royalties to popular British authors.

\section{Bilateral Pressure, TRIPS, and the World Copyright Treaty}

The schizophrenic attitude of the U.S. towards intellectual property rights (strong on patents, weak on copyrights) changed as the structure of the U.S. economy changed after World War II. With the growth of the computer software industry, the rise of large export markets for U.S. films, television programs, videogames, and phonograms, the United States began to run trade surpluses in copyrighted goods even as its overall balance of trade account deteriorated. Siwek (2004) shows that the size of copyrighted industries (as a percentage of gross domestic product) and their export share has continued to expand over the last 15 years.

\footnotetext{
${ }^{4}$ Books with foreign copyright holders had either to be printed in the United States or to have their printing plates manufactured in the United States. This requirement remained substantially unchanged until the United States joined the Berne Convention in 1988.
} 
Intellectual property rights (IPRs) have been a contentious issue for the United States and developing countries for the last 25 years. In the early 1980s, the U.S. Trade Representative (USTR) found that many developing countries-the ASEAN countries prominent among them — had weak intellectual property laws or failed to take adequate measures to enforce them. The USTR threatened countries with loss of their GSP (Generalized System of Preferences) status and other trade-related benefits if they did not take action to strengthen IPRs laws and increase enforcement activities. Between 1985 and 1995, numerous Asian countries, in response to U.S. pressure and to the changing structure of their own economies, strengthened their IPR laws and increased enforcement. The TRIPS provisions of the 1995 WTO Treaty represent a significant step on the road to IPR convergence by both developed and developing countries, as they committed all GATT signatories to establishing IPRs that meet specified minimum standards (Table 1).

TRIPS was intended to harmonize national systems of IPRs as well as to broaden and strengthen the legal rights provided to owners of intellectual property (Zutshi 1998). It forced many middle-income and developing countries to make extensive changes to their IPR laws in the mid-1990s and to spend additional resources on IPR enforcement activities. More surprising is that the United States and Europe also had to enact significant upgrades to their IPR laws to conform to TRIPS. ${ }^{5}$

There have been several significant events regarding intellectual property rights over the last decade since the creation of the TRIPS agreement. Among these are two World Intellectual Property Organization (WIPO) treaties, the Doha Declaration on the TRIPS Agreement and Public Health, significant upgrades of copyright laws in

\footnotetext{
${ }^{5}$ Major changes included increasing patent terms from 17 to 20 years of protection; mandating patent protection to pharmaceutical products; and establishing a system of IPR protection for plants.
} 
developed countries, and the negotiations on the harmonization of substantive patent law, geographical indications, and the protection of traditional knowledge.

The two significant WIPO treaties relating to IPR are the WIPO Copyright Treaty (WCT) and the WIPO Performances and Phonograms Treaty (WPPT). The WIPO Copyright Treaty was implemented in U.S. law by the Digital Millennium Copyright Act (DMCA). In March 2000, the European Council approved the treaty, on behalf of the European Community. While Gabon's accession in December of 2001 provided the necessary 30 countries for the two treaties to enter into force as of 10 February 2006, only 58 countries had ratified the WCT treaty and 57 countries the WPPT treaty. ${ }^{6}$

The treaties clearly articulate the principle that copyright law applies on the Internet as in the off-line world. One stipulation of the treaty is that authors, performers, producers, etc. are able to specify how and when they would like to distribute their music. This exclusive "making available" right covers many different types of dissemination of music, from listen-only services to those that allow the download of permanent copies. It provides the basis for record companies or licensees to develop different forms of business models, examples of which are currently reflected in ventures such as Music Net (involving BMG, EMI and Warner), Press Play (involving Sony Music and Universal), iTunes (Apple), and a number of ventures by independent record companies.

The WIPO treaties also protect the technologies that enable new uses of copyrighted material. The treaties recognize that copyright holders need to use technical measures, such as encryption, passwords and scrambling, in order to manage the delivery of their works to consumers, as well as to protect them from piracy and unauthorized

\footnotetext{
${ }^{6}$ Texts of both treaties can be found at http://www.wipo.int/treaties/en/.
} 
copying. Examples of technical measures include the use of copy control technologies and the use of rights management information to identify content and channel payments digitally to the appropriate copyright holders. The treaties also require governments to protect such measures from hacking and circumvention effectively, which should include outlawing the manufacture and distribution of a range of circumvention devices. ${ }^{7}$

Along with the WCT and WPPT treaties, WIPO also helped make great strides towards the development of a global patent system and harmonization of patent law in September 2001. Their efforts included lobbying countries to ratify the Patent Law Treaty (PLT), which harmonized procedures for patent applications; developing measures to reform the Patent Cooperation Treaty (PCT) of 1970; and beginning negotiations on a Substantive Patent Law Treaty (SPLT). ${ }^{8}$ This "Patent Agenda" was designed to address the failure of the patent system to adequately respond to the international nature of business activities, the high costs of obtaining patents, the workload crisis in patent offices, and time-consuming patent office procedures. ${ }^{9}$

Ironically, just one month later, in October 2001, the Canadian government decided to break drug manufacturer Bayer AG's patent on Cipro over concerns of a "matter of availability" in the case of an anthrax outbreak. One week later, the U.S. government contracted with Bayer AG for 100 million Cipro tablets for $\$ 0.95$ each, far

\footnotetext{
${ }^{7}$ http://www.ifpi.org/site-content/press/20011206.html.

${ }^{8}$ http://www.iprsonline.org/unctadictsd/bellagio/docs/Correa_Bellagio2.pdf.

${ }^{9}$ See Memorandum of the Director General, Agenda for Development of the International Patent System, August 2001, WIPO A/36/14, Geneva, para. 17 - 28.
} 
less than the $\$ 1.77$ the U.S. government had reportedly been paying prior to the Canadian decision to break the Bayer patent. ${ }^{10}$

The Doha Declaration on the TRIPS Agreement and the Public Health, adopted in November 2001, was one of the most important international developments in the area of IPR in WTO since the adoption of the Agreement in 1994. The Doha Declaration was important to developing countries in particular, as the public health consequences have been far reaching. The Declaration has indicated that in cases of conflict between IPR and public health, the former should not be an obstacle to the realization of the latter. This was primarily political in nature, and the economic tradeoff between greater patent protection (namely pharmaceuticals) and social welfare was the focus of debate. In affirming that the TRIPS Agreement, "can and should be interpreted and implemented in a manner supportive of WTO Members' right to protect public health and, in particular, to promote access to medicines for all," ${ }^{11}$ paragraph 4 provides guidance to panels and the Appellate Body for the interpretation of the Agreement's provisions in cases involving public health issues. ${ }^{12}$ This space for interpretation reduces the effect of bilateral pressures and the risk of potential disputes linked to the TRIPS and the implementation of national health policies. In addition to this, least developed countries are not required by the treaty to enforce patent rights on pharmaceuticals until January $1^{\text {st }}$ of 2016 and had until January $1^{\text {st }}$ of 2006 to apply the basic TRIPS Agreement's provisions. This decision

\footnotetext{
${ }^{10}$ http://www.fool.com/news/2001/bayzf011025.htm.

${ }^{11}$ http://www.worldtradelaw.net/doha/tripshealth.pdf.

${ }^{12}$ http://www.iprsonline.org/unctadictsd/bellagio/docs/Correa_Bellagio2.pdf.
} 
allows developing countries to take necessary steps towards improving heath conditions in their respective territories without jeopardizing their economic development. ${ }^{13}$

Over the decade, some European countries have been raising the topic of geographical indications and their scope in international forums. Geographical indications are place names used to identify the origin and quality, reputation or other characteristics of products. Under the TRIPS Agreement, protection is defined in two articles: Articles $22 \& 23$. Article 22 covers all products, which defines a standard level of protection. This says geographical indications have to be protected in order to avoid misleading the public and to prevent unfair competition. Article 23 provides a higher or enhanced level of protection for geographical indications for wines and spirits. During the Doha round of trade negotiations, the two main concerns over geographical indications were a multilateral register for wines and spirits, and extending the higher (Article 23) level of protection beyond wines and spirits. ${ }^{14}$ Disagreement on expansion of Article 23, however, became a thorny issue for many countries, and geographical indications talks have been linked with agricultural negotiations which makes it even more difficult to find a compromise. Negotiations with respect to a multilateral system of notification and registration of geographical indications are continuing in the Doha WTO round. $^{15}$

Traditional Knowledge (TK) has become increasingly important in IPR protection as well, although there are no set international standards as of yet specifically protecting

\footnotetext{
${ }^{13}$ http://www.ciel.org/Publications/Doha_IP.pdf,

${ }^{14}$ http://www.wto.org/english/tratop_e/trips_e/gi background_e.htm.

${ }^{15}$ Doha Work Programme, Preparations of the Sixth Session of the Ministerial Conference, Draft Ministerial Text, World Trade Organization, 26 November 2005.
} 
TK. TK is defined through WIPO as any tradition-based literary, artistic or scientific work, such as performances, inventions, scientific discoveries, designs, etc. ${ }^{16}$ The TRIPS agreement does not specifically deal with TK in the formal sense; instead, it grants monopoly rights by way of patents to inventions, whether products or processes, in all fields of technology only provided that they are new, involve an inventive step and are capable of industrial application. Because of this and from a lack of other agreements, TK has been forced to go through the "normal" means of IPR protection as discussed above, such as low-cost patents, trademarks, copyrights, and geographical indications. WIPO has presented a set of criteria, however, which could be an important first step towards recognition of TK in the IPR world. It involves splitting TK into two separate categories, the first covering biodiversity and medicine, such as traditional agriculture or medical techniques, and the second covering the arts, such as music, designs, and expressions.

Since the late 1990s, preferential trade areas (PTAs)—-typically referred to by government bureaucrats as "free trade areas" (FTAs)—have proliferated around the globe. While PTAs within Asia contain no or very few references to IPRs, the United States has made the inclusion of IPRs a centerpiece of its FTA agreements. The U.S.Morocco FTA contains the "gold standard" package of IPRs provisions that strengthen IPRs and their enforcement beyond the levels specified in the TRIPS Agreement. The package includes extensions of copyright terms; required membership in the WCT and WPPT treaties; broad provisions mandating national treatment with few exceptions; patent terms extensions for pharmaceutical products delayed by the regulatory process

\footnotetext{
${ }^{16}$ Intellectual Property Needs and Expectations of Traditional Knowledge Holders - WIPO Report on Fact-Finding Missions on Intellectual Property and Traditional Knowledge, WIPO, April 2001, p. 25.
} 
from being marketed; banning the export of generic pharmaceuticals to countries experiencing public health crises; mandating the use of licensed software by government agencies; banning compulsory licensing for retransmission of television signals; mandating use of the retail product price (rather than the price of a pirated copy) in calculations of damages for copyright infringement; allowing customs and criminal authorities to pursue violations without a complaint by the rights holder; and mandating copyright damages to be sufficiently high to deter potential violators. Most of these provisions are included in the U.S. FTAs negotiated since 2000 with Bahrain, Jordan, Morocco, Singapore, Chile, and the countries in the Central America-Dominican Republic FTA (El Salvador, Nicaragua, Costa Rica, Guatemala, and Honduras). It is noteworthy that national treatment requires these countries to extend the higher IPR protection granted to the United States to all other countries.

The IPR provisions in the U.S. FTAs are, in some respects, not particularly important, as they affect only a small part of U.S. and APEC trade. They do, however, signal the price that potential APEC partners in an FTA with the United States, e.g. Thailand, Indonesia, and Malaysia, would have to pay to finalize an FTA agreement. And while some of the provisions—-banning compulsory licenses for the rebroadcast of television signals—are likely to be efficient, others—banning exports of generics to countries experiencing public health crises—are more problematic and seem to be in conflict with the Doha Declaration on the TRIPS Agreement and the Public Health (discussed above).

\section{Does Patent Harmonization Increase Global Welfare?}


The economics literature is divided concerning the welfare implications of minimum IPR standards and IPR harmonization. Evanson and Westphal (1995) and Taylor (1998) concluded that a well functioning IPR law is a critical component of the institutional package required for economic development. Helpman (1993) used a dynamic two-country (North-South) model to show that stronger IPRs can reduce welfare in the South and reduce global R\&D. Grossman and Lai (2003) develop a two-country (North-South) model that yields results similar to those generated by the 1995 TRIPS Agreement. We examine this model in more detail below.

\section{A. Grossman and Lai's Theoretical Results}

Several authors (McCalman, 2002; Grossman and Lai, 2004) have investigated the choice of IPR standards by developing and developed countries in the absence of global cooperation on IPR but in the presence of global information, capital, and product flows. Grossman and Lai $(2004,1635-36)$ observe that “[i]t is not obvious how a government ought to set its IPR policy if some of the benefits of its national innovation accrue to foreigners, if its constituents benefit from innovations that are encouraged and take place beyond its borders, and if domestic and foreign firms differ in their ability to innovate.” They consider a world economy with two-countries (North-South) that differ with respect to market size and ability to innovate. Each country has two sectors, one producing a homogeneous good and a second producing a continuum of differentiated products. Designs for the differentiated products emerge from R\&D conducted by individual firms; the designs can be imitated by other firms if the designs are not patentprotected. The optimal patent system is derived for each of the two countries for three 
cases: (1) each country is an autarchy; (2) the two countries trade and independently determine their patent systems; and (3) the two countries trade and agree to use the globally efficient patent system.

In the first case (autarchy), Grossman and Lai (2004, 1637-41) find results broadly similar to those of Nordhaus (1969): optimal patent protection increases as the useful life of the product increases and as the productivity of R\&D expenditures increases; and falls as consumer discount rates increase. Market size has indeterminate effects on the strength of patent protection. In their base case, in which R\&D is produced using a Cobb-Douglass production function, optimal patent protection is positively related to market size.

In the second case (trade in differentiated goods, national treatment, and no parallel imports), the North adopts stronger patent protection than the South due to its higher human capital endowment and the higher productivity of labor in the North than the South; patent protection is, however, lower in both the North and the South than in the closed economy case. ${ }^{17}$

In the third case (globally efficient patent protection which, by definition, maximizes the sum of North and South welfare), Grossman and Lai (2004, 1647-50) show that the welfare of the North increases as Southern patent protection increases, while the welfare of the South increases as Northern patent protection weakens. They show that there is a range of joint patent policies that maximize world welfare but which have vastly different effects on the welfare of each country. Many (but not all) of the welfare-

\footnotetext{
${ }^{17}$ Adding additional countries into the model reduces optimal patent protection for a small country to zero (Grossman and Lai, 1650-51).
} 
maximizing patent combinations require that the North pay a lump-sum to the South if Southern welfare is to be higher than in the second case discussed above.

Finally, efficient patent harmonization (identical patent policies which maximize the sum of North and South welfare) produces an increase in patent protection in both countries as well a gain in welfare in the North. The South requires a lump-sum payment from the North in order to offset the negative effects on Southern welfare generated by the increased flow of royalty payments to the North (Grossman and Lai, 1649-50).

\section{B. The 1994 WTO Agreement: Trading IPRs for Textile Markets?}

Grossman and Lai’s theoretical results concerning the implications of IPR harmonization and strengthening parallels the conventional wisdom on the political economy of the TRIPS Agreement: TRIPS imposed losses on developing countries due to the premature strengthening of their IPRs but were more than compensated for their losses by the provisions in the WTO Agreement providing for the dismantling of the MultiFibre Agreement beginning in 2005 (Harrison, Tarr, and Rutherford, 1997). Table 2 provides data on net licensing and royalty payments to selected developed and developing countries. After the implementation of the TRIPS agreement in 1995, the payments data indicate that net payments by developing countries in APEC increased, while the developed countries realized increases in net receipts. Could the dismantling of the MFA provide the lump sum compensation necessary for developing countries to gain from the TRIPS Agreement?

Prior to the Uruguay Round, textile and clothing trade was governed by the MultiFibre Arrangement (MFA) outside of normal GATT rules and standards. Agreed 
upon as an exception to the GATT of 1974, the MFA established a system of bilateral negotiations established quotas on imports to four economies (US, European Economic Community, Canada, and Norway) of textiles and apparel made from cotton, wool, and synthetic fibre. Quotas were, however, not allocated on the basis of cost efficiency but rather in response to political pressure and to suppress import surges. Thus the MFA was a significant and longstanding departure from GATT principles of non-discrimination.

Over the past 40 years of the quota system, textiles and apparel were increasingly produced with labor-intensive technologies in developing countries, yet significant production continued in capital-intensive developed countries. Thus the MFA became the quintessential example of how developing countries were not adequately represented by the GATT. The Uruguay Round negotiations included proposals from India, Indonesia, Bangladesh, and the International Textiles and Clothing Bureau, all calling for an end to the MFA. Thus, a major accomplishment of the 1994 Uruguay Round for developing countries was the elimination of the MFA and the phasing out all textile and clothing quotas by January 1, 2005.

In the interim, the MFA was replaced by the Agreement on Textiles and Clothing (ATC) in which developed countries have agreed to phase out textile and clothing quotas according to the following schedule:

- 16 percent of products imported in 1990 integrated on January 1, 1995;

- 17 percent of products imported in 1990 integrated on January 1, 1998;

- 18 percent of products imported in 1990 integrated on January 1, 2002;

- 49 percent of products imported in 1990 integrated on December 31, 2004.

The WTO’s Textile Monitoring Body (TMB) found that textile and apparel importers had lagged behind on their obligations, with the amount of restrained trade left to be integrated by the E.U. and the U.S. by December 31, 2004 at 80 and 68 per cent, 
respectively. The ATC also provided a special safeguard mechanism that triggers when an overall increase in covered product imports is found to be causing serious damage to the home country's textile or apparel industry. ${ }^{18}$

Neither the WTO negotiators, who ostensibly added the MFA phaseout and the TRIPS phase-in to the 1994 WTO deal to complete the negotiations, nor the economists who subsequently analyzed the deal (e.g., Harrison, Rutherford, and Tarr 1997), nor the representatives from developing countries with MFA quotas gave much thought as to how the MFA phase-out would affect the developing countries. The simple analysisthat quotas restrain a country's trade-was applied to rationalize the argument that individual developing countries would gain from the removal of quotas. Unfortunately, the economists analyzing this issue all failed to address three important factors: (1) the sustained productivity improvements and higher growth in India’s economy generated after its landmark 1991 reforms; (2) China’s admission to the World Trade Organization and its strong economic growth over the 1995-2005 period; (3) and the assignment of textile-apparel quotas to developing countries who were not the least-cost producers in 1974 and are still not the least-cost producers in 2005.

The 1 January 2005 termination of textile-clothing quotas has already generated very uneven effects across developing countries. Over a 2-3 year period, low-cost developing countries are expected to increase production dramatically, while high-cost developing countries, which were previously protected by quota rights, will face closure of a large proportion of their textile and apparel manufacturing plants. A report issued by

\footnotetext{
${ }^{18}$ Anti-dumping measures and more restrictive rules of origin are being used to replace the quotas in the United States. Developing countries expected to lose productive capacity in this area are asking the U.S. Congress to enact preferential tariff rates to allow them to retain some export business.
} 
the U.S. International Trade Commission (2004) concluded that there will be increased sourcing of textiles and apparel from East and South Asia and less sourcing from ASEAN countries, the Andean countries, Sub-Saharan African countries, some Caribbean countries, and Mexico. ${ }^{19}$

Moving the geographical locus of textile-apparel production from high-cost to low-cost manufacturers will clearly improve world efficiency by reducing production costs, decreasing prices, and increasing the volume of clothing purchases world-wide. As output is increasingly determined by comparative advantage and less by quota allocations, income will also be redistributed throughout the developing world. Thus, the elimination of the MFA becomes a dubious means by which to compensate developing economies for the large anticipated losses due to higher streams of net royalty payments under the TRIPS agreement. It is estimated that a handful of developing countriesChina, India, and Pakistan-will gain handsomely from the MFA phase-out; a few others—-perhaps Vietnam, perhaps Indonesia—will retain some textile-clothing export business; and the vast majority of developing countries will see almost all clothing-textile exports totally disappear over the next decade. The stark reality is that the MFA phaseout is likely to deliver large losses to 35 developing countries with MFA quotas in 1995 and gains to just three developing countries-albeit with over 40 percent of the world's population. ${ }^{20}$ Coupled with TRIPS, the MFA phase-out represents a large transfer of

\footnotetext{
${ }^{19}$ The large number of developing countries losing from the elimination of the MFA-ATC quotas may help to explain why the quota phase-outs were delayed until 2005: to provide the losing developing countries with an additional ten years of benefits prior to the phase-out.

${ }^{20}$ Bangladesh, Brazil, Columbia, Costa Rica, Czech Republic, Dominican Republic, Egypt, El Salvador, Fiji, Guatemala, Honduras, Hong Kong, Hungary, Indonesia, Jamaica, Kenya, South Korea, Macao, Malaysia, Mexico, Oman, Panama, Peru, Philippines, Poland, Romania, Singapore, Slovakia, Slovenia, Sri Lanka, Thailand, Turkey, and Uruguay.
} 
wealth from 35 developing countries to 3 developing countries and to the developed countries. $^{21}$ In sum, Pareto optimality fails big time.

Finally, and most importantly, should the WTO be in the business of forcing developing countries to adopt welfare-reducing IPR institutions in exchange for the welfare-increasing dismantling of non-tariff trade barriers in textiles? In short, probably not, unless it can be shown that the distortions will last for just a short period of time.

\section{Empirical Effects of IPRs on Trade, Investment and Technology Transfer}

Inherent in the inclusion of intellectual property (IP) protection under the scope of the World Trade Organization is the notion that the protection of patents, trademarks and copyrights is somehow 'trade-related'. Exports embody technology and serve as a means of transferring knowledge to foreign markets. Treatment of knowledge in recipient countries thus intuitively should be linked to trade flows. Protection of intellectual property is also clearly a factor in a firm’s decision to transfer technology more directly to those markets through establishments of foreign subsidiaries, franchises, or license arrangements. The second-best nature of IP protection renders the drawing of theoretical conclusions on just how international flows might be impacted by harmonization of standards quite indeterminate.

Very simply, intellectual property protection grants market power to the owner of the invention or creation. The stronger is the protection and the enforcement of the property right, the larger is the firm's monopoly power. Thus, firms may decide to

\footnotetext{
${ }^{21}$ Under MFA, the quota rents were assigned to the developing country. After January 1, 2005, the developing countries which remain in textile-apparel production loss the quota rents but receive producer surplus on their increased production. If the loss in rents is greater than the producer surplus, then all developing countries incur losses after the MFA phase-out.
} 
restrict sales in markets where IPRs are strongly protected to extract monopoly rents $-\mathrm{a}$ market power effect. That is, the market structure may be less competitive in markets in which foreign imitators are not present, and this might dampen exports as the firm seeks higher cost markups. At the same time, the firm will incur a lower cost of protecting IP in markets with strong protection - an efficiency effect which would expand sales in countries that strengthen IP protection. Thus, a classical ambiguity exists between the level of IP protection in foreign markets and the propensity of knowledge-intensive firms to sell to those markets.

The relationships become more complex when alternative modes of delivery are considered. A firm may serve a foreign market at arm's length with exports, by a local subsidiary with foreign direct investment, or by franchising or licensing relationships with a local partner. Each decision is influenced by the nature of the industry, the mechanisms for the transfer of technology, the IP regime in place, and the methods by which imitation might be conducted. A weak IP regime increases the probability of imitation which dissuades foreign investors. However, stronger IP protection tends to shift the mode of entry from direct investment through multinational enterprises toward licensing. Thus the impact of strengthened IP protection on exports, foreign investment, and licenses are interrelated and complex.

IPR regimes have strengthened dramatically since 1990. The Park-Ginarte Index of patent rights (with 0 the lowest and 5 the highest) registered just 2.06 in 1960. Developed countries registered 2.5 and developing countries 1.5 in 1960. Despite large increases in world income between 1960 and 1990, the Park-Ginarte Index increased only to 2.46 in 1990 . The increase to 3.07 in 2000 reflects a variety of factors, including 
bilateral pressure from the United States and the European Union, TRIPS, and rising incomes. The gap between developing and developed countries barely changed, with less than 5 percent of the gap closed over the index's 40-year coverage.

Fortunately, a series of empirical studies have emerged in recent years to clarify the relationships involved. A pioneering effort by Maskus and Konan (1994) found that strong IP protection tends to increase bilateral imports and foreign investment over values predicted for countries by gravity equations. Maskus and Penubarti (1995) refined the analysis by using the Helpman-Krugman monopolistic competition model of trade to predict trade flows in the presence of IP protection and other instrumental variables. They provided strong evidence that stronger IP protection has a positive impact on bilateral manufacturing imports. The impact of IP protection was found to be greater the larger the country's market.

Lee and Mansfield (1996) used U.S. firm survey data to show that the strength of a country's IP protection is positively correlated with the aggregate volume of U.S. FDI inflows to that country. Using a gravity equation approach, Smith (2001) considered how IP protection influences a wider range of modes to supply foreign markets. She found that stronger IP protection within a country increased the propensity of U.S. firms to export to that market. Additionally, with strong foreign IP protection, U.S. firms are relatively more likely to use foreign affiliates and license arrangements rather than export sales. Thus, overall international linkages are strengthened with IP protection, with local distribution being favored over exports. Yang and Maskus (2001) also found that licensing is more likely to take place the stronger is IP protection. 
A survey of U.S. manufacturing firms by Mansfield $(1994,1995)$ provided evidence that the importance of IPRs differs across sectors, even those that might be identified as 'technology intensive.' Respondents were far less concerned about IP protection on investment decisions regarding sales and distribution outlets. IP protection was viewed as far more important for investments in manufacturing and production, most especially when technology transfers were involved.

Using an original firm-level survey as well as country characteristic data for transition economies, Javorcik (2004) considers empirically how IP protection impacts the volume as well as the distribution of FDI. She finds that strong IP protection is positively correlated with inward foreign investment in sectors that have been identified as 'technology-intensive.' Additionally, the stronger is IP protection, the more likely are high-technology firms to undertake foreign investments in manufacturing plants and distribution sales rather than just in distribution sales.

Will developing countries lose by adopting stronger IPRs? Using a sample of countries with GDPs below the median GDP and an index of average patent protection between 1960 and 1990, Ginarte and Park (1997) found that stronger patent rights had no effect on growth. Maskus (2001) argues that stronger IPRs tend to stimulate economic growth in developing countries which are open to trade and foreign investment. Yet the link between growth and trade has recently been hotly debated. Some economists argue that the chain of causation is from growth to trade; others argue that export-oriented economies promote growth; and a third group notes that both trade and growth are endogenous outcomes of more fundamental economic and institutional factors (Frankel 1999). 
We also note that the causal chain leading from stronger IPRs to more foreign investment and then to stronger (transitory or permanent) GDP growth is tenuous. Even if the empirical literature connecting IPRS and foreign direct investment is well founded, other literature finds only tenuous connections between FDI and growth despite extensive theoretical results pointing to a possible connection (Carcovic and Levine 2005). A series of studies (Moran, Graham, and Blomström 2005; Lipsey and Sjöholm 2005; Blomström and Sjöholm 1999; Long 2005; and Kokko 1994) helps to resolve this dilemma. Lipsey and Sjoholm $(2005,5)$ find that differences in counties' abilities to benefit from FDI are due to "varying levels of indigenous human resources, to disparate degrees of private sector sophistication, to differing levels of competition, and to contrasting host country policies toward trade and investment”. Empirical studies by Long (2005) on FDI in China and Moss, Ramachandran, and Shah (2005) on FDI in East Africa show "that FDI in which local affiliates operate within a relatively open trade and investment policy framework greatly benefits the host country. FDI in which local affiliates produce for the domestic market behind trade barriers, with joint venture and local content requirements, has a much less positive impact and often subtracts from hostcountry welfare.” In other words, the effectiveness of stronger IPRs in stimulating growth depends on the capability of the domestic economy to implement the IPRs and to absorb foreign direct investment and foreign technologies efficiently. This leads us to the tentative conclusion that stronger IPRs are more likely to stimulate growth in middleincome developing countries than in low-income developing countries.

\section{Global Copyright: Finally, In Crisis?}


Robert Merges (2000) has wryly observed that copyright law is constantly in crisis. The advent of the copier in the 1960s and the VCR in the early 1980s both brought forth loud protests from copyright industries and from the academy that the "sky is falling” and that publishing and movie industries would soon fail to be profitable. To the contrary, fair use copying has become the norm, and the VCR and DVD players have spawned a huge after-market for films in VCR and DVD formats in both developed and developing economies.

Today’s claims concerning a global crisis in copyright law are more ominous: the combination of digitization of creative works and spread of broadband internet networks capable of distributing them has dramatically reduced the costs to consumers and intermediaries of copying and distributing copyrighted materials. This combination has dramatically increased rates of consumer piracy in all countries but particularly in Eastern Europe and the Asia-Pacific region. Table 3 provides estimates of piracy rates in APEC countries and finds that they are economically significant in virtually all APEC countries. $^{22}$

Perhaps Robert Merges will again be proven correct. European manufacturers of computers, MP3 players, DVD players, and the like are lobbying the European Commission to repeal copyright levies on the sale of such equipment which are redistributed to musical and video artists owning copyrights. Their claim is that new digital controls on consumer copying are beginning to alleviate the problem, and that the copyright levies on electronic video and music players and burners should be repealed. Musicians are opposed to the repeal.

\footnotetext{
${ }^{22}$ While the United States is not listed in the table, it has economically significant piracy rates in music, consumer software, and business software. ADD CITE.
} 
Consider the possibility that Robert Merges is wrong and a real crisis in copyright exists. Has the crisis been identified and is a multilateral policy response in place or being developed? On the one hand, the speed with which a group of countries moved to ameliorate this problem is amazing and virtually unprecedented. The World Copyright Treaty (WCT) was signed by over 40 countries in December 1996, just 2-3 years after widespread use of the worldwide web began, and the United States and the European Union have significantly upgraded their IP laws to implement the treaties. On the hand, most developing countries and some developing countries have not signed the WCT.

The Digital Millennium Copyright Act (DMCA) was passed to ensure the protection of copyright works in the digital world by fortifying the technological blocks on access and copying of those works within a legal framework. It was signed into law on October 28, 1998 as part of the U.S. implementations of the World Intellectual Property Organization (WIPO) Copyright Treaty and Performances and Phonograms Treaty (WPPT). The DMCA implemented these recommendations and added more of its own, thereby providing copyright owners with even broader protection than provided in the two WIPO treaties. ${ }^{23}$

The DMCA contains four main provisions:

1. a prohibition on circumventing access controls [1201(a)];

2. an access control circumvention device ban [1201 (a)];

3. a copyright protection circumvention device ban [1201(b)]; and,

4. a prohibition on the removal of copyright management information (CMI) $[1202(b)] .^{24}$

\footnotetext{
${ }^{23}$ http://www.chillingeffects.org/anticircumvention/faq.cgi\#QID123.

${ }^{24}$ http://thomas.loc.gov/cgi-bin/cpquery/0?\&\&db_id=cp105\&\&r_n=hr796.105\&\&sel=DOC\&
} 
The first provision prohibits defeating the access control measure that protects or limits access to digital information. Defeating the access control measure, or "circumventing a technological measure,” means to descramble a scrambled work, to decrypt an encrypted work, or otherwise to avoid, bypass, remove, deactivate, or impair a technological measure without the authority of the copyright owner. The second provision bans trafficking in devices that circumvent access controls. The Scandinavian teenager, who found the hole in the DVD encryption code and posted his finding on the Internet, would have been in violation of this provision . The third provision bans trafficking in technology that circumvents technological measures that limit the ability to reproduce a copyrighted work. An example of this kind of technological protection is an encoding technique that prevents a music CD from being played on a computer and therefore prevents its songs from being copied to the computer's hard disc. The fourth provision bans the alteration of copyright management information or providing false copyright management information. Copyright management information is information conveyed in connection with a copyrighted work for the purposes of identifying its origin; such information could include the title, author, name of the copyright owner, terms and conditions for use of the work, and identifying numbers or symbols referring to the above information. ${ }^{25}$ The European Union has passed parallel but slightly different legislation. $^{26}$

\footnotetext{
${ }^{25}$ http://depts.washington.edu/uwcopy/Copyright_Law/DMCA/Provisions.php. The first three provisions are distinguishable from the fourth, in that the first two provisions focus on technological protection systems that provide access control to the copyright owner, while the third provision prohibits circumvention of technological protections against unauthorized duplication and other potentially copyright infringing activities. Another DMCA provision of DMCA is designed to protect internet service providers (ISPs), allowing ISPs to escape liability for the actions of its users so long as they did not know or have reason to know that their users were violating a copyright holder's rights. The DMCA allows for both civil remedies and criminal penalties for violations under the anti-circumvention provisions. The civil and criminal penalties in the DMCA are well defined, in sharp comparison to the WIPO treaties, with their
} 
On the other hand, despite the speed with which some countries have moved to ratify the WCT and to pass enabling legislation, most countries have not become a party to the WCT or have not passed similar legislation or have not enforced these law--and therein lies the root of the problem. These countries can become centers of piracy for individuals in other countries wishing to download copyrighted works. Off-shore sites in international waters with computers linked to the web present additional problems. The problem of piracy has become compounded by the combination of broadband transmission with digitization. A "window of opportunity" of just an hour could now

relatively lax and subjective penalty clauses. In the United States, if the violations of the DMCA are determined to be willful and for commercial purposes or private financial gain, the court can order significant fines as well as jail time. Civil cases are brought in federal district court where the court has broad authority to grant injunctive and monetary relief. Injunctions can be granted forbidding the distribution of the tools or products involved in the violation. The court may also order the destruction of the tools or products involved in the violation. The court can also award actual damages, profits gained through infringement, and attorney's fees. If an individual held in violation of the DMCA commits another such violation within the three-year period following the judgment, the court may increase the damages up to triple the amount that would otherwise be awarded. In circumstances involving innocent violators, it is up to the courts to decide whether to reduce damages. But, in the case of nonprofit library, archives or educational institutions, the court must remit damages if it finds that the institution did not know of the violation. If the circumvention violations are determined to be willful and for commercial or private financial gain, first time offenders may be fined up to $\$ 500,000$, imprisoned for five years, or both. For repeat offenders, the maximum penalty increases to a fine of $\$ 1,000,000$, imprisonment for up to ten years, or both. Criminal penalties are not applicable to nonprofit libraries, archives, and educational institutions.

${ }^{26}$ Much like the Digital Millennium Copyright Act (DMCA) passed by the United States, the European Community also has their version, called the EU Copyright Directive (EUCD). Differing copyright regimes among European countries were seen as major obstacles to efficient trade, and the EC set about drafting a Directive on the subject between 1997 and 2000. The Directive sought to create a level playing field for the enforcement of intellectual property rights in different EU countries, by bringing enforcement measures into line across the EU, especially in those countries where the enforcement of intellectual property rights is currently weakest. The Directive covers infringements of all intellectual property rights (both copyright and industrial property, such as trademarks or designs), and concentrates on infringements carried out for commercial purposes or which cause significant harm to rights-holders. The EUCD does NOT cover music downloading or file sharing (it leaves this up to individual countries to enforce their own laws), but is instead concentrated on provisions of encoding and protections found in the two WIPO treaties and the DMCA. Also, similarly to the DMCA, the EUCD paves the way for injunctions to halt the sale of counterfeit or pirated goods, provisional measures such as precautionary seizures of suspected offenders' bank accounts, evidence-gathering powers for judicial authorities and powers to force offenders to pay damages to rights-holders to compensate for lost income. ${ }^{26}$ 
result in all issues of a leading journal or an entire series of reference works, e.g. North Holland's Handbook of Economics series, being downloaded and widely redistributed. With the stock of copyrighted works so exposed, the choices for policymakers are stark.

First, policymakers could increase copyright terms to provide more protection. Such extensions have been recently granted in the United States and Europe. Cheng (2004) has closely examined the U.S. Sonny Bono Copyright Term Extension Act (CTEA) passed in 1998 which extends copyright terms from life of the author plus 50 years to life of the author plus 75 years. Cheng (2004), Cheng and La Croix (2006), Landes and Posner (2003), and Breyer (2003) have all concluded that the effect of copyright term extension on incentives to imagine and market creative works is trival and that the main reason for the extension appears to be to extend the copyright term of valuable copyrights which would otherwise expire. We can find no efficiency rationales for this type of extension and conclude that retroactivity provisions drove the enactment of the law.

Second, governments could increase penalties for violations of copyright laws and provide additional resources for their enforcement. In countries which are net importers of intellectual property, these will be unpopular measures that could be difficult for the government to sustain, particularly given the decentralized nature of the copyright piracy in most developed and developing countries.

Third, governments could work together to establish new forms of intellectual property for some forms of property that meet consumer needs appropriately while providing reduced incentives for piracy. Software is one type of work for which copyright protection is obviously too long, while the availability of patent protection for 
some software may provide protection which is too broad (La Croix, 1992). While opening the door to more specialized categories of IPRs may be opening a Pandora's box, the ubiquity and value of software in the workplace and the home calls for more differentiated protection to remedy the ongoing dissipation of rents in the innovation and distribution processes for these products.

\section{Conclusion}

The “property rights” approach to economics rightly encourages the establishment of property rights in valuable goods, as well-defined property rights typically maximizes the value of the good. ${ }^{27}$ This perspective must, however, be modified for goods which are public goods, as one person's use does not deprive another from using the good, as it does with private goods. We conclude that it is important to establish intellectual property rights in intellectual innovations while at the same time limiting those rights to allow widespread access to the new works. Establishing property rights in new products and new intellectual innovations embodied in new products and processes is necessary to establish sufficient incentives for individuals and corporations to undertake R\&D. The scope, depth, and enforcement of IPRs is, however, likely to differ across countries according to their economic and political institutions, their per capita income, and their capability to engage in and disseminate the fruits of R\&D.

\footnotetext{
${ }^{27}$ The establishment of property rights is, however, also costly, and the transaction costs of establishing these rights may limit their scope and delineation.
} 


\section{References}

Breyer, Stephen. 2003. “Dissenting Opinion,” Eldred et al. v. Ashcroft 537 U.S. 186.

Carcovic, Maria, and Ross Levine (2005). “Does Foreign Direct Investment Accelerate Economic Growth?” In Moran, Graham, Blomstrm, eds, Does Foreign Direct Investment Promote Development.

Cheng, Xiaopeng. Intellectual Property Rights, Innovation in Developing Countries, and Copyright Term Extension. Unpublished doctoral dissertation, University of Hawaii-Manoa, 2004.

Cheng, Xiaopeng, and Sumner La Croix (2006). “To Infinity and Beyond! Are Ever Lengthening Copyright Terms Efficient?” Unpublished manuscript, Department of Economics, University of Hawaii.

Chin, Judith and Grossman, Gene M. (1990). "Intellectual Property Rights and NorthSouth Trade”, in R.W. Jones and A. O. Krueger, eds., The Political Economy of International Trade, Cambridge MA: Basil Blackwell Publishers.

Deardoff, Alan V. (1992). "Welfare Effects of Global Patent Protection,” Economica 59, 35-51.

Evanson, Robert E., and Larry E. Westphal (1995). “Technological Change and Technology Strategy,” in Jere Behrman and T.N. Srinivasan, eds, Handbook of Development Economics, Vol. 3A. New York: North Holland Press.

Gallini, Nancy and Suzanne Scotchmer (2002). "Intellectual Property: When is it the Best Incentive System?” Innovation Policy and the Economy 2, 51-77.

Giannakas, Konstantinos (2002). "Infringement of Intellectual Property Rights: Causes and Consequences,” American Journal of Agriculture Economics, 84(2):482-494.

Griliches, Zvi (1994). "Productivity, R\&D, and the Data Constraint,” American Economic Review 84(1) March, 1-23.

Grossman, Gene M., and Edwin L.-C. Lai (2004). "International Protection of Intellectual Property,” American Economic Review 94(5) December, 1635-53.

Harrison, Glenn, David Tar, and Thomas F. Rutherford (1997). "Quantifying the Uruguay Round,” Economic Journal 107, 1405-1430.

Javorcik, Beata Smarzynska (2004). “The Composition of Foreign Direct Investment and Protection for Intellectual Property Rights: Evidence from Transition Economies,” European Economic Review 48, 39-62. 
Kawaura, Akihiko, and Sumner J. La Croix (1995) "Japan's Shift from Process to Product Patents in the Pharmaceutical Industry: A Stock Market Event Analysis," Economic Inquiry 33(1), 88-103.

Khan, B. Zorina, and Kenneth L. Sokoloff. 1998. "Two Paths to Industrial Development and Technological Change," in Maxine Berg and Kristine Bruland, eds, Technological Revolutions in Europe, 1760-1860. Cheltenham: Edward Elgar.

Khan, B. Zorina, and Kenneth L. Sokoloff. 2001. "The Early Development of Intellectual Property Institutions in the United States," Journal of Economic Perspectives 15(3) Summer, 233-246.

Konan, Denise Eby, Sumner J. La Croix, James Roumasset, and Jeffrey Heinrich (1995). "Intellectual Property Rights in the Asia-Pacific Region: Problems, Patterns, and Policy,” Asian-Pacific Economic Literature 9(2), 13-35.

La Croix, Sumner J. (1992). "Property Rights in Computer Software: Some Comments on the Evolving International Framework," in Kiyoshi Abe and William Gunther, eds, Economic, Industrial and Managerial Coordination Between Japan and the USA: A Comparative Analysis. New York: Macmillan Press.

La Croix, Sumner J. (1995). "The Rise of Global Intellectual Property Rights and their Impact in Asia,” Asia Pacific Issues. Honolulu: East-West Center, August 1995.

La Croix, Sumner J., and Akihiko Kawaura (1996). "Korea's Shift from Process to Product Patents in the Pharmaceutical Industry: An Event Study of the Impact of American Pressure on Korean Firms," International Economic Journal 10(1), 10924.

La Croix, Sumner J., and Denise Eby Konan (2002). "Intellectual Property Rights in China: American Pressure and Chinese Resistance," The World Economy 25(6), 759-788.

Lall, Sanjaya (2003). “Indicators of the Relative Importance of IPRs in Developing Countries,” Research Policy 32, 1657-1680.

Lamoreaux, Naomi R., and Kenneth L. Sokoloff (1996). "Long-Term Change in the Organization of Inventive Activity," Proceedings of the National Academy of Sciences 93 November, 12686-12692.

Lamoreaux, Naomi R., and Kenneth L. Sokoloff (1999). "Inventors, Firms, and the Market for New Technology in the Late Nineteenth and Early Twentieth Centuries,” Naomi R. Lamoreaux, Daniel M.G. Raff, and Peter Temin, eds, Learning by Doing in Markets, Firms, and Countries. Chicago: University of Chicago Press, 19-57. 
Lamoreaux, Naomi R., and Kenneth L. Sokoloff (2003). "Intermediaries in the U.S. Market for Technology, 1870-1920,” in Stanley L. Engerman, Philip T. Hoffman, Jean-Laurent Rosenthal, and Kenneth L. Sokoloff, eds, Finance, Intermediaries, and Economic Development. New York: Cambridge University Press, 209-246.

Landes, William M., and Richard A. Posner (2003). “Indefinitely Renewable Copyright,” University of Chicago Law Review 70, 471-518.

Lee, J. Y. and E. Mansfield (1996). “Intellectual Property Protection and U.S. Foreign Direct Investment,” Review of Economics and Statistics 78, 181-186.

Lybbert, Travis J. (2002). “On Assessing the Cost of TRIPS Implementation”, World Trade Review 1(3), 309-19.

Mansfield, Edwin (1994). Intellectual Property Protection, Foreign Direct Investment, and Technology Transfer. International Finance Corporation Discussion Paper no. 27.

Maskus, Keith E. (2000). Intellectual Property Rights in the Global Economy. Washington, D.C.: The Institute for International Economics.

Maskus, Keith E. (2002). "Regulatory Standards in the WTO: Comparing Intellectual Property Rights with Competition Policy, Environmental Protection, and Core Labor Standards,” World Trade Review 1(2), 135-52.

Maskus, Keith E. and Mohan Penubarti (1995). "How Trade Related are Intellectual Property Rights?” Journal of International Economics 39, 227-248.

McCalman, Phillip (2004). "Foreign Direct Investment and Intellectual Property Rights: Evidence from Hollywood's Global Distribution of Movies and Videos,” Journal of International Economics 62(1):107-23.

McCalman, Phillip (2002). "National Patents, Innovation and International Agreements," Journal of International Trade and Economic Development 11(1), 1-14

McCalman, Phillip (2004). "Protection for Sale and Trade Liberalization: An Empirical Investigation,” Review of International Economics 12(1), 81-94.

Merges, Robert P. (2000). "On Hundred Years of Solitude: Intellectual Property Law, 1900-2000,” California Law Review 88, 2189-2240.

Moran, Theodore H., Edward M. Graham, and Magnus Blomström (2005). “Introduction and Overview,” in Moran, Graham and Blomström, eds, Does Foreign Direct Investment Promote Development? Washington, D.C.: Institute for International Economics and Center for Global Development. 
Mowrey, David C. (1983). “The Relationship Between Intra-Firm and Contractual Forms of Industrial Research in American Manufacturing, 1900-1940,” Explorations in Economic History 20 October, 351-74.

Mowrey, David C. (1995). “The Boundaries of the U.S. Firm in R\&D,” in Naomi R. Lamoreaux and Daniel M.G. Raff, eds, Coordination and Information: Historical Perspectives on the Organization of Enterprise. Chicago: University of Chicago Press.

Nordhaus, William D. (1969) Invention, Growth and Welfare: A Theoretical Treatment of Techonological Change. Cambridge MA: M.I.T. Press.

O’Donoghue, Ted, Scotchmer, Suzanne and Thisse, Jacques-Francois (1998). "Patent Breadth, Patent Life, and the Pace of Technological Progress,” Journal of Economics and Management Strategy 7(1), 1-32.

Rapp, Richard T., and Richard P. Rozek (1990). "Benefits and Costs of Intellectual Property Protection in Developing Countries,” Journal of World Trade 24, 75102.

Rasiah, Rajah (2002). “TRIPS and Industrial Technology Development in East and South Asia,” European Journal of Development Research 14(1), 171-99.

Scherer, F. M. and Watal, Jayashree (2002). "Post-TRIPS Options for Access to Patented Medicines in Developing Nations, Journal of International Economic Law 5(4), 913-39.

Schiff, Eric. 1971. Industrialization without Patents: The Netherlands, 1869-1912, Switzerland, 1850-1907. Princeton: Princeton University Press.

Scotchmer, Suzanne (2004). “The Political Economy of Intellectual Property Treaties,” Journal of Law, Economics, and Organization 20(2):415-37.

Siwek, Stephen E. (2004). Copyright Industries in the United States. Economists Inc.

Smith, Pamela J. (2001). "How do Foreign Patent Rights Affect U.S. Exports, Affiliate Sales, and Licenses? Journal of International Economics 55, 411-439.

Srinivasan, T.N. (2000). “The TRIPS Agreement: A Comment Inspired by Frederick Abbott’s Presentation.” Mimeo, Yale University, November.

Stevenson-Yang, Anne, and Ken De Woskin (2005). “China Destroys the IP Paradigm,” Far Eastern Economic Review 168(3), 9-18. 
U.S. International Trade Commission (2004). Textiles and Apparel: Assessment of the Competitiveness of Certain Foreign Suppliers to the US Market. Washington, D.C: January 2004.

Wade, Robert H. (2003). "What Strategies are Viable for Developing Countries Today? The World Trade Organization and the Shrinking of 'Development Space'," Review of International Political Economy 10(4), 621-644.

Yang and Keith E. Maskus (2001). "Intellectual Property Rights and Licensing: An Econometric Investigation,” Weltwirtschafliches Archiv 137, 58-79.

Zhutshi, B.K. (1998). "Bringing TRIPS into the Multilateral Trading System,” in Jagdish Bhagwati and Mathias Hirsch, eds, The Uruguay Round and Beyond: Essays in Honor of Arthur Dunkel. Ann Arbor: University of Michigan Press. 


\section{Table 1}

\section{Major Features of the TRIPS Agreement}

1. GATT members must apply the principle of national treatment to all foreign IPR owners (Articles 1(3), 3).

2. All GATT members must comply with the central provisions of four conventions:

a. $\quad$ Paris Convention (Article 2(1));

b. $\quad$ Berne Convention (Article 9(1)) without moral rights provisions;

c. $\quad$ Rome Convention (Article 14);

d. and Washington Treaty (Article 35) with the modification that compulsory licenses of integrated circuit technology is prohibited.

3. GATT members cannot exclude certain classes of products from being patented (with limited exceptions specified in TRIPS); pharmaceuticals cannot be excluded from product or process patents (Article 27(1)).

4. Countries must protect patents for 20 years from date of application (Article 28).

5. Patent holders no longer have an obligation to work their patent locally if they supply the market's demand for the good with imports (Article 28).

6. Pharmaceutical products in the pipeline, i.e., which were developed earlier and are just now completing safety and efficacy procedures to come to market, must receive at least five years of protection (Articles 70(8), (9)).

7. GATT members must adopt either a patent system or a sui generis system for protecting plant varieties (Article 27).

8. The detailed enforcement procedures specified in the GATT must be incorporated into each member's national laws (Article 41).

9. GATT members must adopt stricter enforcement measures, including border controls, to prevent imports of counterfeit goods (Articles 51-60).

10. TRIPs eliminates compulsory licensing of trademarks as well as local linkage requirements (Articles 15-24). Marks may be assigned with or without the transfer of the business to which the trademark belongs.

11. TRIPs requires copyright protection of computer programs (10(1) and data bases (Article 10(2)). All computer programs must receive at least 50 years of protection (Article 12).

12. TRIPs requires all GATT members protect trade secrets (Article 39). 
La Croix and Konan, Intellectual Property Rights, p. 39

13. GATT members must protect original industrial designs for at least 10 years (Article 26).

14. TRIPs requires that authors and their successors in title have the right to authorize or prohibit the commercial rental to the public of originals or copies of their copyright works (Article 11). The substantive effect is to allow copyright owners to charge royalties or other fees for commercial rental of their works.

15. TRIPs requires that service marks as well as trade marks be protected (Article 15).

16. Commercial data submitted for regulatory approval of pharmaceutical or agricultural chemical products shall be protected against unfair commercial use (Article 39). 
La Croix and Konan, Intellectual Property Rights, p. 40

\section{Table 2}

\section{Estimates of Net Royalty and Licence Transfers in Selected EU and APEC Countries}

(in millions current US\$)

\begin{tabular}{|c|c|c|c|c|}
\hline Country & 1992 & 1995 & 2000 & 2003 \\
\hline United States & 15,680 & 23,370 & 26,760 & 28,180 \\
\hline France & -490 & -470 & 270 & 1,500 \\
\hline Germany & $-2,430$ & $-2,790$ & $-2,760$ & -980 \\
\hline United Kingdom & 610 & 880 & 1,510 & 2,520 \\
\hline Canada & n.a. & $-1,511$ & $-1,510$ & $-2,265$ \\
\hline Japan & $-4,140$ & $-3,410$ & -780 & 1,270 \\
\hline China & n.a. & n.a. & $-1,281$ & $-3,548$ \\
\hline Thailand & -271 & -629 & -701 & $-1,261$ \\
\hline Singapore & n.a. & $-1,645$ & $-3,525$ & $-3,137$ \\
\hline Malaysia & n.a & n.a. & -528 & -762 \\
\hline Australia & -685.4 & -713 & -660 & -874 \\
\hline Mexico & -387 & -370 & -364 & -524 \\
\hline Chile & -39 & -48 & -288 & -221 \\
\hline
\end{tabular}

Source: IMF Balance of Payments (2004). 
Table 3

Estimates of Losses from Piracy in Asia-Pacific Countries: 2003

\begin{tabular}{|c|c|c|c|c|c|c|c|c|c|}
\hline \multirow[t]{2}{*}{ Country } & \multicolumn{2}{|c|}{ Motion Pictures } & \multicolumn{2}{|c|}{ Records \& Music } & \multicolumn{2}{|c|}{$\begin{array}{l}\text { Business Software } \\
\text { Applications }\end{array}$} & \multicolumn{2}{|c|}{$\begin{array}{l}\text { Entertainment } \\
\text { Software }\end{array}$} & \multirow{2}{*}{$\begin{array}{l}\text { Books } \\
\text { Loss }\end{array}$} \\
\hline & Loss & Piracy Level & Loss & Piracy Level & Loss & Piracy Level & Loss & Piracy Level & \\
\hline \multirow{2}{*}{\multicolumn{10}{|c|}{$\begin{array}{l}\text { Australia } \\
\text { Hong Kong }\end{array}$}} \\
\hline & & & & & & & & & \\
\hline India & 77 & $60 \%$ & 6 & $40 \%$ & 187 & $73 \%$ & 113.3 & $84 \%$ & 36.5 \\
\hline Indonesia & 29 & $92 \%$ & 44.5 & $87 \%$ & 94 & $88 \%$ & NA & NA & 30 \\
\hline Malaysia & 38 & $50 \%$ & 40 & $45 \%$ & 77 & $63 \%$ & NA & NA & 9 \\
\hline Pakistan & 12 & $95 \%$ & 70 & $100 \%$ & 9 & $83 \%$ & NA & NA & 44 \\
\hline \multicolumn{10}{|l|}{ People's Republic of } \\
\hline China & 178 & $95 \%$ & 286 & $90 \%$ & 1787 & $92 \%$ & 568.2 & $96 \%$ & 40 \\
\hline Philippines & 33 & $89 \%$ & 22.2 & $40 \%$ & 33 & $72 \%$ & NA & $95 \%$ & 45 \\
\hline \multicolumn{10}{|l|}{ Singapore } \\
\hline South Korea & 40 & $20 \%$ & 3.5 & $20 \%$ & 275 & $48 \%$ & 248.4 & $36 \%$ & 38 \\
\hline Taiwan & 42 & $44 \%$ & 58 & $42 \%$ & 83 & $43 \%$ & 261.8 & $42 \%$ & 20 \\
\hline Vietnam & 7 & $100 \%$ & NA & NA & 24 & $92 \%$ & NA & NA & 12 \\
\hline
\end{tabular}

Source: International Intellectual Property Association.

Note: All losses are \$US millions. 
Table 4

\section{WCT and WPPT: Contracting Parties in Asia}

\begin{tabular}{|c|c|c|c|c|c|}
\hline \multicolumn{3}{|c|}{ World Copyright Treaty } & \multicolumn{3}{|c|}{ World Performances and Phonograms Treaty } \\
\hline $\begin{array}{l}\text { Contracting } \\
\text { Party }\end{array}$ & Status & $\begin{array}{l}\text { Entry into } \\
\text { Force }\end{array}$ & $\begin{array}{l}\text { Contracting } \\
\text { Party }\end{array}$ & Status & $\begin{array}{l}\text { Entry into } \\
\text { Force }\end{array}$ \\
\hline Indonesia & In Force & 6-Mar-02 & Indonesia & In Force & 15-Feb-05 \\
\hline Japan & In Force & 6-Mar-02 & Japan & In Force & 9-Oct-02 \\
\hline Mongolia & In Force & 25-Oct-02 & Mongolia & In Force & 25-Oct-02 \\
\hline Philippines & In Force & 4-Oct-02 & Philippines & In Force & 4-Oct-02 \\
\hline South Korea & In Force & 24-Jun-04 & & & \\
\hline
\end{tabular}

Source: World Intellectual Property Rights Organization. 